\title{
Prognostic significance of Body Mass Index in patients with localized renal cell carcinoma
}

\author{
Chengtao Wang ${ }^{1}$, Zebin Chen ${ }^{2}$, Jun Dong ${ }^{1}$, Bixiu Wen ${ }^{1}$, Yong Fang ${ }^{2}$ \\ ${ }^{1}$ Department of Radiation Oncology, First Affiliated Hospital of Sun Yat - Sen University, Guangzhou, \\ China; ${ }^{2}$ Department of Urology, First Affiliated Hospital of Sun Yat - Sen University, Guangzhou, China
}

\section{ABSTRACT}

Objective: To investigate the relationship between the pretreatment body mass index (BMI) and the clinical outcomes in patients with localized stage I - III renal cell carcinoma (RCC) surgically treated.

Materials and Methods: From January 2000 to December 2012, 798 patients with stage I - III RCC were recruited from First Affiliated Hospital and Cancer Center of Sun Yat - Sen University. Patients were divided into two groups of BMI $<25 \mathrm{~kg} / \mathrm{m} 2$ or BMI $\geq 25 \mathrm{~kg} / \mathrm{m} 2$ according to the World Health Organization classifications for Asian populations. The differences in the long-term survival of these two BMI groups were analyzed.

Results: The 5 - year failure - free survival rates for BMI $<25 \mathrm{~kg} / \mathrm{m} 2$ and BMI $\geq 25$ $\mathrm{kg} / \mathrm{m} 2$ groups were $81.3 \%$ and $93.3 \%$, respectively $(\mathrm{P}=0.002)$, and the 5 - year overall survival rates were $82.5 \%$ and $93.8 \%$, respectively $(\mathrm{P}=0.003)$. BMI was a favored prognostic factor of overall survival and failure - free survival in a Cox regression model.

Conclusions: Pretreatment body mass index was an independent prognostic factor for Chinese patients surgically treated, localized stage I - III RCC.

\section{ARTICLE INFO}

\section{Keywords:}

Body Mass Index; Carcinoma, Renal Cell; Prognosis

Int Braz J Urol. 2018; 44: 1147-55

Submitted for publication:

December 09, 2017

Accepted after revision:

June 11, 2018

Published as Ahead of Print:

September 15, 2018

\section{INTRODUCTION}

Renal cell carcinoma (RCC) is one of the most common urologic malignancies, and its incidence has steadily increased in recent decades. Several risk factors for developing of RCC have been reported, including smoking, hypertension and obesity (1).

Stratification of the patients with RCC into categories with different risk of local recurrence, progression and survival would improve the standard of preoperative patient's counseling and treatment planning. Several anatomical, clinical, histological and molecular variables can predict the probabilities of recurrence, progression, and both overall and cancer - specific survival of the patients with RCC (2).

The relationship between Body Mass Index (BMI) and the prognosis of cancer is not consistent. According to some published studies, a high BMI was associated with a favorable prognosis for various tumor types, including head and neck cancer (3), esophageal cancer (4), colon cancer (5) and endometrial cancer (6). However, the results 
of some studies showed that patients with a higher BMI had a worse prognosis for breast cancer (7), and prostate cancer (8). In renal cell carcinoma, obesity seems to increase the risk of developing RCC (1).

Whereas, more recent studies conducted in Western countries indicate that obese patients treated with surgery for RCC may have a more favorable prognosis than patients with normal BMI (9-12). It is unknown whether the same associations are seen in Chinese patients, who have a different body composition from White and Black populations. As we all known, different ethnic groups may show clinically significant increases in fat composition or glucose at lower BMI than those predicted in established BMI cut points.

Therefore, the aim of this study was to assess the influence of BMI, using the World Health Organization (WHO) categories recommended for Asians (13), on treatment results in Chinese patients with surgically treated, localized stage I - III RCC.

\section{MATERIALS AND METHODS}

\section{Patients}

By using the departmental surgical database of our two institutions (First Affiliated Hospital and Cancer Center of Sun Yat - Sen University), we identified 798 patients aged 18 years old who were treated with radical nephrectomy for unilateral, sporadic localized stage I - III RCC between 2000 and 2012. Data collected from each patient included age at diagnosis, gender, pretreatment BMI, pretreatment hemoglobin $(\mathrm{Hb})$, pretreatment alkaline phosphatase (ALP), pretreatment platelets (PLT), TNM stage, histological subtype and survival time. BMI was calculated as the patient's weight on day 1 of admission (in kilograms) divided by the patient's height squared (in meters).

Tumors were classified in accordance with the 2002 TNM staging system. Histological subtypes were stratified in accordance with the 2002 AJCC / UICC classification, and only tumors of clear - cell, chromophobe, and papillary histology were included. The BMI was categorized based on WHO recommendations for Asians.

\section{Statistical analysis}

All events were measured from the date of surgery, and statistical tests were performed using SPSS V17.0 (SPSS Inc., Chicago, IL). The actuarial rates were calculated with the Kaplan - Meier method, and the differences were compared with the $\log$ - rank test. The time to the first defining event was assessed for the following endpoints: failure free survival (FFS - disease failure at any site), and overall survival (OS - all cause mortality). The survival rates were calculated using the Kaplan Meier method and compared with the log - rank test. A 2 - tailed P value of less than 05 was considered statistically significant.

The entire cohort was analyzed using the Cox proportional hazards model for OS and FFS. Potentially important prognostic factors considered in the modeling process were patient gender (male vs. female), age ( $\geq 50$ years vs $<50$ years), symptoms at presentation (yes vs. no), histology (chromophobe vs. papillary vs clear cell), pTNM stage (III vs. II vs. I), Hb (non - anemia vs. anemia), PLT ( $>300$ vs. $\leq 300)$, ALP ( $>70$ vs. $\leq 70$ ), tumor necrosis (yes vs. no) and BMI ( $\geq 25 \mathrm{~kg} / \mathrm{m}^{2}$ vs. $<25 \mathrm{~kg} / \mathrm{m}^{2}$ ).

The last follow-up visit was in June 2015, with a median follow-up period of 46 months.

\section{RESULTS}

Table- 1 summarizes the clinical and pathologic characteristics of 798 patients according to the WHO BMI subgroups. The mean age was 51 years (range: 19 - 84 years) and the mean BMI was $23.8 \mathrm{~kg} / \mathrm{m}^{2}$ (range: $14.4-41.7 \mathrm{~kg} / \mathrm{m}^{2}$ ) for the entire group. Three hundred and thirty - seven (42.2\%) patients had a BMI less than $25 \mathrm{~kg} / \mathrm{m}^{2}$, and $461(51.2 \%)$ had a BMI equal or greater than $25 \mathrm{~kg} / \mathrm{m}^{2}$. When comparing risk parameters between BMI categories, the two BMI groups showed similar demographics, such as in the age, histology, pTNM stage, ALP and tumor necrosis. Aside from these factors, gender, symptoms at presentation, pretreatment $\mathrm{Hb}$ and PLT were significantly different. There were more female patients and patients with symptoms at presentation in BMI 
Table 1 - Baseline Characteristics by BMI Group.

\begin{tabular}{|c|c|c|c|c|}
\hline \multirow{2}{*}{ Characteristics } & \multirow{2}{*}{ Total (\%) } & \multicolumn{2}{|c|}{ BMI Group } & \multirow[b]{2}{*}{$P$ value } \\
\hline & & $<25(\%)$ & $\geq 25(\%)$ & \\
\hline Case (Percentage) & $798(100)$ & $337(42.2)$ & $461(57.8)$ & \\
\hline $\begin{array}{l}\text { Mean BMI } \\
\text { [mean(range)] }\end{array}$ & $\begin{array}{c}23.8 \\
(14.4-41.7)\end{array}$ & $\begin{array}{c}20.7 \\
(14.4-22.9)\end{array}$ & $\begin{array}{c}26.0 \\
(23-41.7)\end{array}$ & \\
\hline $\begin{array}{l}\text { Age }(y) \\
\text { [mean(range)] }\end{array}$ & $51(19-84)$ & $51(19-81)$ & $52(19-84)$ & \\
\hline$<50$ year & $383(48.0)$ & $168(49.9)$ & $215(46.6)$ & 0.369 \\
\hline$\geq 50$ year & $415(52.0)$ & $169(50.1)$ & $246(53.4)$ & \\
\hline Sex & & & & $<0.001$ \\
\hline Male & $545(68.3)$ & $206(61.1)$ & $339(73.5)$ & \\
\hline Female & $253(31.7)$ & $131(38.9)$ & $122(26.5)$ & \\
\hline Symptoms at presentation & & & & 0.008 \\
\hline Yes & $296(37.1)$ & $143(42.4)$ & $153(33.2)$ & \\
\hline No & $502(62.9)$ & $194(57.6)$ & $308(66.8)$ & \\
\hline Histology & & & & 0.406 \\
\hline Clear cell renal carcinoma & $720(90.2)$ & $302(89.6)$ & 418(90.7) & \\
\hline Papillary renal cell carcinoma & $43(5.4)$ & $22(6.5)$ & $21(4.6)$ & \\
\hline Chromophobe renal carcinoma & $35(4.4)$ & $13(3.9)$ & $22(4.8)$ & \\
\hline pTNM stage & & & & 0.070 \\
\hline I & $596(74.7)$ & $238(70.6)$ & $358(77.7)$ & \\
\hline ॥ & $171(21.4)$ & $85(25.2)$ & $86(18.7)$ & \\
\hline III & $31(3.9)$ & $14(4.2)$ & $17(3.7)$ & \\
\hline $\mathrm{Hb}$ & & & & 0.003 \\
\hline $\begin{array}{l}\text { Male: } \mathrm{Hb}<120 \\
\text { Female: } \mathrm{Hb}<110\end{array}$ & $106(13.3)$ & $59(17.5)$ & $47(10.2)$ & \\
\hline $\begin{array}{l}\text { Male: } \mathrm{Hb} \geq 120 \\
\text { Female: } \mathrm{Hb} \geq 110\end{array}$ & $692(86.7)$ & $278(82.5)$ & $414(89.8)$ & \\
\hline PLT & & & & 0.017 \\
\hline$\leq 300$ & $690(85.5)$ & $280(83.1)$ & $410(88.9)$ & \\
\hline$>300$ & $108(13.5)$ & $57(16.9)$ & $51(11.1)$ & \\
\hline ALP & & & & 0.894 \\
\hline$\leq 70$ & $445(55.8)$ & $187(55.5)$ & $258(56.0)$ & \\
\hline$>70$ & $353(44.2)$ & $150(44.5)$ & $203(44.0)$ & \\
\hline Tumor necrosis & & & & 0.660 \\
\hline Yes & $111(13.9)$ & $288(85.5)$ & $399(86.6)$ & \\
\hline No & $687(86.1)$ & 49 (14.5) & 62 (13.4) & \\
\hline
\end{tabular}

$\mathbf{B M I}=$ body mass index; $\mathrm{Hb}$ = hemoglobin; $\mathbf{P L T}=$ platelets; $\mathbf{A L P}$ = alkaline phosphatase 
less than 25 group. Patients with a BMI less than 25 were significantly more likely to have lower pretreatment $\mathrm{Hb}$ and higher pretreatment PLT (P $=0.003, \mathrm{P}=0.017$, respectively; Table-1). Laparoscopic partial nephrectomy was performed in 39 (4.9\%) patients, radical nephroureterectomy was performed in $435(54.5 \%)$ patients, open partial nephrectomy completed in 183 patients (22.9\%), and 141 of them had a laparoscopic radical nephrectomy (17.7\%). The distribution of surgery modality was balanced in both BMI groups.

Surgery complications were as follow: hemorrhage and hematoma occurred in 21 patients; peritoneal injury in 36 patients; abdominal organ injury in 5 patients; vascular injury in 13 patients; urinary fistula in 7 patients; pleura injury in 3 patients; wound infection in 8 patients and severe hypercapnia in 2 patients. At a median follow-up period of 46.0 months, 11.2\% (89 / 798) patients developed tumor progression (31 with tumor recurrence, 58 with distant metastasis) and 10.5\% (84 / 798) patient were dead. The 5 - year failure - free survival rates for $\mathrm{BMI}<25 \mathrm{~kg} / \mathrm{m}^{2}$ and $\mathrm{BMI} \geq 25 \mathrm{~kg}$ $/ \mathrm{m}^{2}$ groups were $81.3 \%$ and $93.3 \%$, respectively (P $=0.002$ ) and the 5 - year overall survival rates were $82.5 \%$ and $93.8 \%$, respectively $(\mathrm{P}=0.003)$. Lower BMI was associated significantly with poor prognosis. Patients with preoperative BMI less than $25 \mathrm{~kg} /$ $\mathrm{m}^{2}$ had a significantly reduced rate of survival than those BMI equal or greater than $25 \mathrm{~kg} / \mathrm{m}^{2}$ with regard to FFS and OS (Figures 1 and 2).

Univariable analyses of the factors influencing FFS and OS are shown in Table-2. Univariable analysis demonstrated that the presence of symptoms at presentation, age, pTNM stage, tumor necrosis, non - anemia, ALP, BMI and thrombocytosis were significant predictors of FFS and OS (Table-2).

Stepwise multivariable analysis showed that BMI (HR, 0.54; $\mathrm{P}=0.029)$ was an independent predictor of OS, along with the presence of symptoms at presentation (HR, 1.68; $\mathrm{P}=0.031)$, pTNM stage $(\mathrm{HR}, 2.30 ; \mathrm{P}<001)$, age (HR, 1.72; $\mathrm{P}=0.023$ ) and non-anemia (HR, $0.55 ; \mathrm{P}=0.025)$ (Table-3). Stepwise multivariable analysis showed that BMI (HR, 0.53; P $=0.022$ ) was an independent predictor of FFS, along with the presence of symptoms at presen-
Figure 1 - Overall survival by BMI group among Chinese patients with RCC.

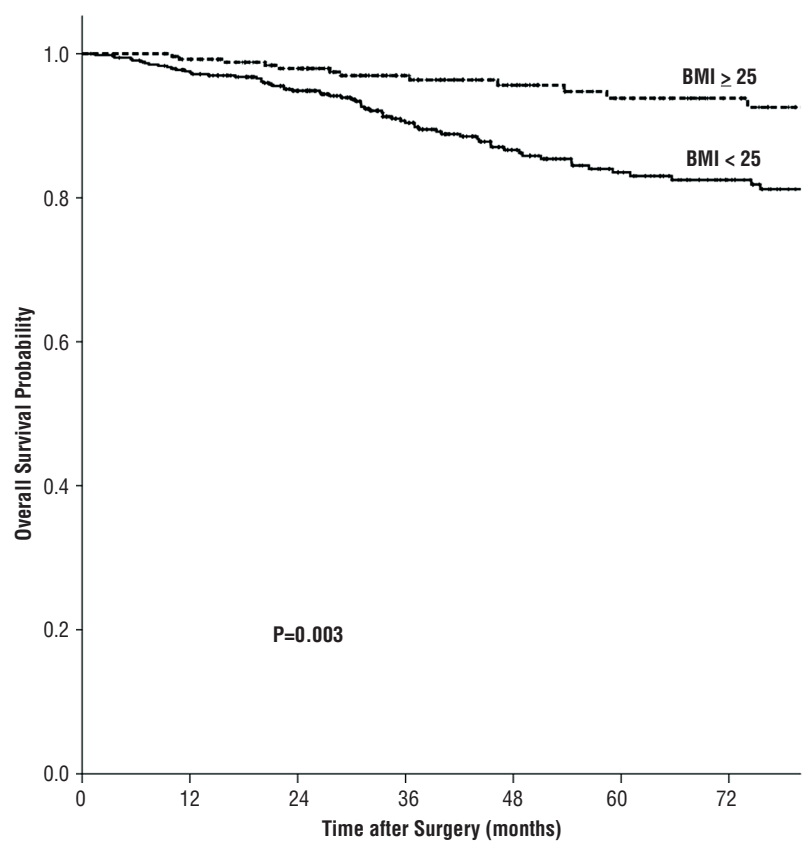

Figure 2 - Failure Free Survival by BMI group among Chinese patients with RCC.

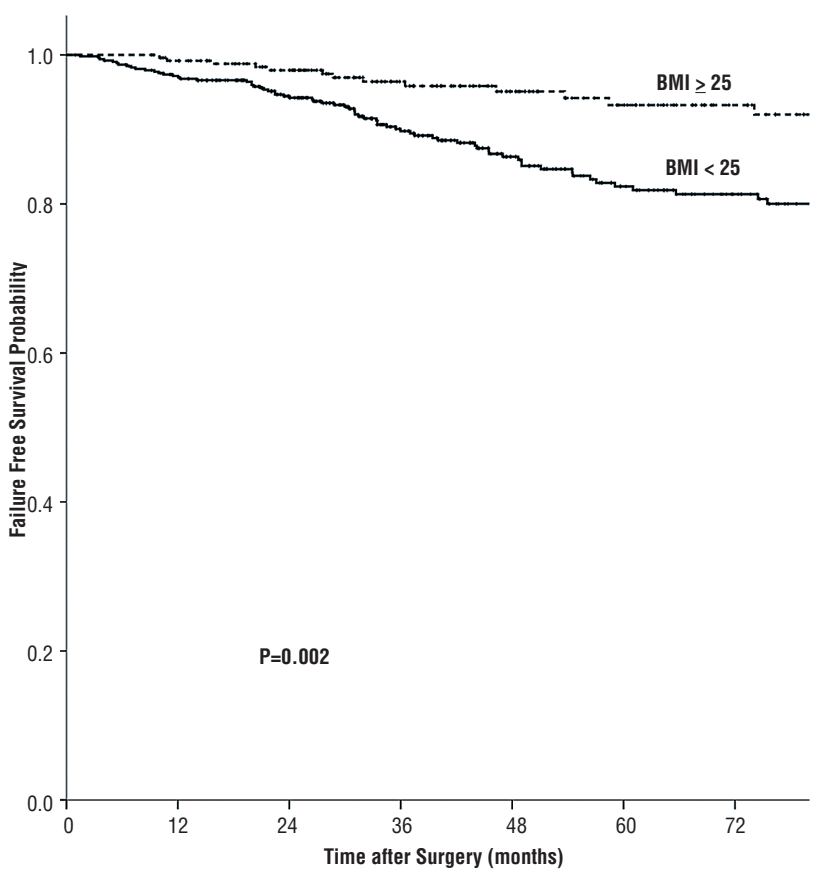

tation (HR, 1.60; $\mathrm{P}=0.043)$, pTNM stage $(\mathrm{HR}$, 2.59; $\mathrm{P}<001)$, age $(\mathrm{HR}, 1.75 ; \mathrm{P}=0.016)$ and non - anemia (HR, 0.60; $\mathrm{P}=0.045)$ (Table-3). 
Table 2 - Pretreatment BMI Effect on Different Endpoint: univariate Analysis in Cox Regression Model.

\begin{tabular}{lcccccc}
\hline \multirow{2}{*}{ Characteristics } & \multicolumn{3}{c}{ FFS } & \multicolumn{3}{c}{ OS } \\
\cline { 2 - 7 } & HR & $95 \% \mathrm{Cl}$ & $\mathrm{p}$ value & $\mathrm{HR}$ & $95 \% \mathrm{Cl}$ & $\mathrm{p}$ value \\
\hline Gender (male vs female) & 1.50 & $0.92-2.45$ & 0.102 & 1.38 & $0.84-2.26$ & 0.201 \\
Age ( $\geq$ 50 years vs $<50$ years) & 1.99 & $1.27-3.10$ & 0.002 & 2.03 & $1.28-3.21$ & 0.003 \\
Symptoms at presentation (yes vs no) & 2.81 & $1.83-4.32$ & 0.000 & 2.94 & $1.88-4.58$ & 0.000 \\
Histology (Chromophobe vs Papillary vs Clear & 1.56 & $0.75-3.25$ & 0.233 & 1.63 & $0.77-3.45$ & 0.207 \\
cell) & 3.36 & $2.53-4.47$ & 0.000 & 3.12 & $2.34-4.18$ & 0.000 \\
pTNM stage(III vs Ilvsl) & 0.30 & $0.19-0.48$ & 0.000 & 0.27 & $0.17-0.42$ & 0.000 \\
Hb (non-anemia vs anemia) & 2.68 & $1.69-4.25$ & 0.000 & 2.89 & $1.81-4.61$ & 0.000 \\
PLT (>300 vs $\leq 300)$ & 5.89 & $2.84-12.2$ & 0.000 & 3.65 & $2.22-5.99$ & 0.000 \\
ALP $(>70$ vs $\leq 70)$ & 3.08 & $1.98-4.78$ & 0.000 & 3.22 & $2.05-5.05$ & 0.000 \\
Tumor necrosis (yes vs no) & 0.45 & $0.27-0.77$ & 0.003 & 0.45 & $0.26-0.78$ & 0.004 \\
BMI Group & & &
\end{tabular}

$\mathbf{B M I}=$ body mass index; $\mathbf{H b}=$ hemoglobin; $\mathbf{P L T}=$ platelets; $\mathbf{A L P}=$ alkaline phosphatase

Table 3 - Pretreatment BMI Effect on Different Endpoint: Multivariate Analysis in Cox Regression Model.

\begin{tabular}{lcccccc}
\hline \multirow{2}{*}{ Characteristics } & \multicolumn{3}{c}{ FFS } & \multicolumn{3}{c}{ OS } \\
\cline { 2 - 7 } & HR & $95 \% \mathrm{Cl}$ & $\mathrm{p}$ value & $\mathrm{HR}$ & $95 \% \mathrm{Cl}$ & $\mathrm{p}$ value \\
\hline Age ( $\geq 50$ years vs $<50$ years) & 1.75 & $1.11-2.75$ & 0.016 & 1.72 & $1.08-2.76$ & 0.023 \\
Symptoms at presentation (yes vs no) & 1.60 & $1.02-2.52$ & 0.043 & 1.68 & $1.05-2.69$ & 0.031 \\
pTNM stage(III vs II vs I) & 2.59 & $1.83-3.64$ & 0.000 & 2.30 & $1.62-3.28$ & 0.000 \\
Hb (non-anemia vs anemia) & 0.60 & $0.36-0.99$ & 0.045 & 0.55 & $0.33-0.93$ & 0.025 \\
PLT (>300 vs $\leq 300)$ & 1.22 & $0.72-2.08$ & 0.456 & 1.33 & $0.77-2.27$ & 0.306 \\
ALP $(>70$ vs $\leq 70)$ & 2.04 & $0.91-4.57$ & 0.083 & 1.94 & $0.86-4.37$ & 0.111 \\
Tumor necrosis (yes vs no) & 1.29 & $0.78-2.11$ & 0.321 & 1.38 & $0.83-2.30$ & 0.210 \\
BMI Group & 0.53 & $0.31-0.91$ & 0.022 & 0.54 & $0.31-0.94$ & 0.029 \\
$\left(\geq 25 \mathrm{~kg} / \mathrm{m}^{2}\right.$ vs $\left.<25 \mathrm{~kg} / \mathrm{m}^{2}\right)$ & & & & & & \\
\hline
\end{tabular}

$\mathbf{B M I}=$ body mass index; $\mathbf{H b}$ = hemoglobin; $\mathbf{P L T}=$ platelets; $\mathbf{A L P}=$ alkaline phosphatase

\section{DISCUSSION}

To our knowledge, several epidemiological studies have suggested that obesity is a risk factor for the development of RCC $(1,11,14)$. Due to the high rate of comorbidities, obesity is frequently considered to represent a major risk factor for complications after surgery (15). Previous reports have identified postoperative complications correlating with a high BMI (16-18). However, there are conflicting data relating obesity as a risk factor affecting overall or progression - free survival. Since 1991 when $\mathrm{Yu}$ et al. found a paradoxical positive association between obesity and overall and disease - free survival, there have been no prospective studies further evaluating this finding 
(19). A more contemporary retrospective review of 400 patients undergoing nephrectomy for RCC by Kamat et al. appears to confirm a more favorable prognosis and disease specific survival in overweight and obese patients when compared to normal weight patients (20). With regard to urologic neoplasms, it was shown that a high BMI does not affect oncologic outcomes after surgery. All these studies were conducted in Western countries. The body composition profile of Asian populations differs from that of white and black populations (13). Some studies conducted in Japan and Korea also demonstrated this phenomenon $(12,21)$. The present study is the furst to investigate the influence of obesity on RCC prognosis in a Chinese population. In this study, we examined the association between BMI and other clinical / pathological characteristics, and evaluated the prognostic association of BMI with FFS and OS in Chinese patients with RCC who underwent radical or partial nephrectomy. We found pretreatment BMI was a favorable prognostic factor for Chinese patients with stage I - III RCC. Although obesity predisposed to an increased risk for developing RCC, the prognosis for obese patients treated with surgery was no worse and possibly better than normal weight subjects.

In this retrospective study, clinical / pathological factors significantly impacting FFS and OS for the study population were similar to previously published factors including age older than 50 years at surgery, symptoms at presentation, pTNM stage. Obese patients were more likely to have favorable clinical and pathologic conditions at diagnosis, including younger, less symptoms at presentation, lower stage, lower PLT and lower anemia when compared with under - to - normal weight patients. We therefore carefully adjusted for age, pTNM stage, symptom presence, baseline $\mathrm{Hb}$, ALP and PLT, which may be related to patient survival. Although adjustment for other important risk factors associated with survival weakened the association for both OS and FFS, the association between obesity and RCC prognosis remained strong and highly significant. Being obese at the time of surgery might have a positive prognostic effect in patients. This result is in accordance with the retrospective studies. Parker et al. evaluated
970 patients with RCC and were unable to identify obesity (BMI $\geq 30 \mathrm{~kg} / \mathrm{m}^{2}$ ) as a prognostic factor (HR 0.90, $0.65-1.23, \mathrm{P}=0.488$ ) for CSS in their multivariate analysis, which also included the prognostic factors: Mayo Clinic Stage, size, TNM stage groups, nuclear grade and tumor necrosis. They concluded that BMI offers little additional prognostic information beyond the accepted prognostic features $(10,22)$. Being obese at the time of surgery might have a positive prognostic effect in patients.

The mechanism by which preoperative obesity may improve RCC survival is not well understood, although mechanisms linking obesity with RCC incidence have long been studied (23). RCC is a heterogeneous and complex disease (24), and the histologic subtypes of RCC differ with respect to genetic, pathologic, and clinical parameters (25-27). On the basis of this evidence, the relationship between obesity and RCC prognosis might be subtype specific. Furthermore, recent studies have shown that the association between obesity and the risk of developing RCC is subtype specific (28-30). Nevertheless, in the previous studies assessing the association between obesity and RCC survival, histologic subtype has been considered as a simple variable that is divided into two groups, cRCC and non - cRCC (31-34), or only patients with cRCC were included $(9,35)$. The relationship between obesity and RCC prognosis might be subtype specific in our study was not significant.

Some protein factors and signals in adipose tissue that suppress RCC progression have been reported (36). For example, adipose tissue synthesize leptin and the circulating levels of leptin are strongly related to obesity. Leptin has also been shown to play an important role in stimulating pro - inflammatory $\mathrm{T}$ helper $1 \mathrm{im}$ mune responses (37). In contrast, a change in the predominant immunologic response from $\mathrm{T}$ helper 1 to $\mathrm{T}$ helper 2 has been reported to correlate with increasing RCC stage (38). Therefore, as proposed by Rasmuson et al., leptin might play a pivotal role in delaying RCC progression (39). Another study showed an association between preoperative nutritional deficiency and poor OS and disease - free survival in RCC patients who 
underwent renal surgery (40). Patients with higher BMI, who generally have large appetites and high lipid concentrations, may adequately preserve their fat and muscle mass, thus allowing better nutritional status and potential survival advantage $(41,42)$. It may be plausible that obesity indicates favorable general health condition rather than it being responsible for improved outcomes.

The present study had some weaknesses. First, the study was retrospective, and the median follow-up time of 46.0 months for patients still alive was short. Second, our study lacked a central review of pathology, although most of the large multicenter studies did. Instead, urologic pathologists reviewed all specimens at each institution. Third, we could not assess potential prognostic factors, such as smoking, molecular markers, and sarcomatoid features in all patients. These factors may allow the identification of patients at high risk and affect the prognosis. However, our study includes the most widely accepted independent prognostic factors of nonmetastatic RCC, including age, pTNM stage, and tumor necrosis. Last, all of our study subjects were Chinese, and the distribution of BMI or cut - off value for Asian populations may be different than those for Western populations. Therefore, our results may not be directly applicable to Western populations. Taken together, a multi - institutional prospective study with a large number of patients would be required to confirm the present finding. Furthermore, basic biologic research would be needed to explain the contradictory effects of BMI on the risk and prognosis of RCC.

In conclusion, these findings suggest that pretreatment high BMI prior to renal surgery is associated with improved OS, FFS when compared with low BMI in Chinese population. This evidence may provide new insight into the effects of preoperative high BMI on improvements in RCC survival, and this could help physicians in predicting overall prognosis. Further research is needed to explain the biological mechanisms responsible for the benefit of high BMI on improved RCC survival, and to determine whether other modifiable lifestyle factors contribute to RCC survival.

\section{CONFLICT OF INTEREST}

None declared.

\section{REFERENCES}

1. Chow WH, Gridley G, Fraumeni JF Jr, Järvholm B. Obesity, hypertension, and the risk of kidney cancer in men. $\mathrm{N}$ Engl $\mathrm{J}$ Med. 2000;343:1305-11.

2. Jonasch E, Gao J, Rathmell WK. Renal cell carcinoma. BMJ. 2014;349:g4797.

3. Pai PC, Chuang CC, Tseng CK, Tsang NM, Chang KP, Yen TC, et al. Impact of pretreatment body mass index on patients with head-and-neck cancer treated with radiation. Int J Radiat Oncol Biol Phys. 2012;83:e93-e100.

4. Park SM, Lim MK, Shin SA, Yun YH. Impact of prediagnosis smoking, alcohol, obesity, and insulin resistance on survival in male cancer patients: National Health Insurance Corporation Study. J Clin Oncol. 2006;24:5017-24.

5. Simkens LH, Koopman M, Mol L, Veldhuis GJ, Ten Bokkel Huinink D, et al. Influence of body mass index on outcome in advanced colorectal cancer patients receiving chemotherapy with or without targeted therapy. Eur J Cancer. 2011;47:2560-7.

6. Mauland KK, Trovik J, Wik E, Raeder MB, Njølstad TS, Stefansson IM, et al. High BMI is significantly associated with positive progesterone receptor status and clinico-pathological markers for non-aggressive disease in endometrial cancer. $\mathrm{Br} \mathrm{J}$ Cancer. 2011;104:921-6.

7. Dawood S, Broglio K, Gonzalez-Angulo AM, Kau SW, Islam R, Hortobagyi GN, et al. Prognostic value of body mass index in locally advanced breast cancer. Clin Cancer Res. 2008;14:171825.

8. Efstathiou JA, Chen MH, Renshaw AA, Loffredo MJ, D'Amico AV. Influence of body mass index on prostate-specific antigen failure after androgen suppression and radiation therapy for localized prostate cancer. Cancer. 2007;109:1493-8.

9. Waalkes S, Merseburger AS, Kramer MW, Herrmann TR, Wegener G, Rustemeier J, Hofmann R, Schrader M, Kuczyk MA, Schrader AJ. Obesity is associated with improved survival in patients with organ-confined clear-cell kidney cancer. Cancer Causes Control. 2010;21:1905-10.

10. Donat SM, Salzhauer EW, Mitra N, Yanke BV, Snyder ME, Russo P. Impact of body mass index on survival of patients with surgically treated renal cell carcinoma. J Urol. 2006;175:46-52.

11. van Dijk BA, Schouten LJ, Kiemeney LA, Goldbohm RA, van den Brandt PA. Relation of height, body mass, energy intake, and physical activity to risk of renal cell carcinoma: results from the Netherlands Cohort Study. Am J Epidemiol. 2004;160:1159-67. 
12. Jeon HG, Jeong IG, Lee JH, Lee CJ, Kwak C, Kim HH, et al. Prognostic value of body mass index in Korean patients with renal cell carcinoma. J Urol. 2010;183:448-54.

13. [No authors] WHO Expert Consultation. Appropriate bodymass index for Asian populations and its implications for policy and intervention strategies. Lancet. 2004;363:15763. Erratum in: Lancet. 2004;363:902.

14. Oh SW, Yoon YS, Shin SA. Effects of excess weight on cancer incidences depending on cancer sites and histologic findings among men: Korea National Health Insurance Corporation Study. J Clin Oncol. 2005;23:4742-54.

15. Pemberton LB, Manax WG. Relationship of obesity to postoperative complications after cholecystectomy. Am J Surg. 1971;121:87-90.

16. Wu XS, Wu WG, Li ML, Yang JH, Ding QC, Zhang L, et al. Impact of being overweight on the surgical outcomes of patients with gastric cancer: a meta-analysis. World J Gastroenterol. 2013;19:4596-606.

17. Pi-Sunyer FX. Medical hazards of obesity. Ann Intern Med. 1993;119(7 Pt 2):655-60.

18. Kodera Y, Sasako M, Yamamoto S, Sano T, Nashimoto A, Kurita A; Gastric Cancer Surgery Study Group of Japan Clinical Oncology Group. Identification of risk factors for the development of complications following extended and superextended lymphadenectomies for gastric cancer. $\mathrm{Br}$ J Surg. 2005;92:1103-9.

19. Yu ML, Asal NR, Geyer JR. Later recurrence and longer survival among obese patients with renal cell carcinoma. Cancer. 1991;68:1648-55.

20. Kamat AM, Shock RP, Naya Y, Rosser CJ, Slaton JW, Pisters LL. Prognostic value of body mass index in patients undergoing nephrectomy for localized renal tumors. Urology. 2004;63:46-50.

21. Lee WK, Byun SS, Kim HH, Rha KH, Hwang TK, Sung GT, et al. Characteristics and prognosis of chromophobe nonmetastatic renal cell carcinoma: a multicenter study. Int J Urol. 2010;17:898-904.

22. Parker AS, Lohse CM, Cheville JC, Thiel DD, Leibovich $B C$, Blute ML. Greater body mass index is associated with better pathologic features and improved outcome among patients treated surgically for clear cell renal cell carcinoma. Urology. 2006;68:741-6.

23. Calle EE, Kaaks R. Overweight, obesity and cancer: epidemiological evidence and proposed mechanisms. Nat Rev Cancer. 2004;4:579-91.

24. Deng FM, Melamed J. Histologic variants of renal cell carcinoma: does tumor type influence outcome? Urol Clin North Am. 2012;39:119-32, v.

25. Schuetz AN, Yin-Goen Q, Amin MB, Moreno CS, Cohen C, Hornsby CD, et al. Molecular classification of renal tumors by gene expression profiling. J Mol Diagn. 2005;7:206-18.
26. Furge KA, Lucas KA, Takahashi M, Sugimura J, Kort EJ, Kanayama $\mathrm{HO}$, et al. Robust classification of renal cell carcinoma based on gene expression data and predicted cytogenetic profiles. Cancer Res. 2004;64:4117-21.

27. Cohen HT, McGovern FJ. Renal-cell carcinoma. N Engl J Med. 2005;353:2477-90.

28. Dal Maso L, Zucchetto A, Tavani A, Montella M, Ramazzotti $V$, Talamini $R$, et al. Renal cell cancer and body size at different ages: an Italian multicenter case-control study. Am J Epidemiol. 2007;166:582-91.

29. Lowrance WT, Thompson RH, Yee DS, Kaag M, Donat SM, Russo P. Obesity is associated with a higher risk of clearcell renal cell carcinoma than with other histologies. BJU Int. 2010;105:16-20.

30. Purdue MP, Moore LE, Merino MJ, Boffetta P, Colt JS, Schwartz KL, et al. An investigation of risk factors for renal cell carcinoma by histologic subtype in two case-control studies. Int J Cancer. 2013;132:2640-7.

31. Komura K, Inamoto T, Black PC, Koyama K, Katsuoka Y, Watsuji T, et al. Prognostic significance of body mass index in Asian patients with localized renal cell carcinoma. Nutr Cancer. 2011;63:908-15.

32. Steffens S, Ringe KI, Schroeer K, Lehmann R, Rustemeier J, Wegener $G$, et al. Does overweight influence the prognosis of renal cell carcinoma? Results of a multicenter study. Int J Urol. 2013;20:585-92.

33. Choi Y, Park B, Jeong BC, Seo SI, Jeon SS, Choi HY, et al. Body mass index and survival in patients with renal cell carcinoma: a clinical-based cohort and meta-analysis. Int $\mathrm{J}$ Cancer. 2013;132:625-34.

34. Park B, Jeong BC, Seo SI, Jeon SS, Choi HY, Lee HM. Influence of body mass index, smoking, and blood pressure on survival of patients with surgically-treated, low stage renal cell carcinoma: a 14-year retrospective cohort study. J Korean Med Sci. 2013;28:227-36.

35. Ohno Y, Nakashima J, Nakagami Y, Satake N, Gondo T, Ohori $M$, et al. Sex and the clinical value of body mass index in patients with clear cell renal cell carcinoma. $\mathrm{Br} \mathrm{J}$ Cancer. 2013;109:1899-903.

36. Trayhurn P. Endocrine and signalling role of adipose tissue: new perspectives on fat. Acta Physiol Scand. 2005;184:285-93.

37. La Cava A, Alviggi C, Matarese G. Unraveling the multiple roles of leptin in inflammation and autoimmunity. J Mol Med (Berl). 2004;82:4-11.

38. Onishi T, Ohishi Y, Goto H, Tomita M, Abe K. An assessment of the immunological status of patients with renal cell carcinoma based on the relative abundance of T-helper 1- and -2 cytokineproducing CD4+ cells in peripheral blood. BJU Int. 2001;87:755-9. 
39. Rasmuson T, Grankvist K, Jacobsen J, Olsson T, Ljungberg B. Serum insulin-like growth factor-1 is an independent predictor of prognosis in patients with renal cell carcinoma. Acta Oncol. 2004;43:744-8.

40. Morgan TM, Tang D, Stratton KL, Barocas DA, Anderson $\mathrm{CB}$, Gregg JR, et al. Preoperative nutritional status is an important predictor of survival in patients undergoing surgery for renal cell carcinoma. Eur Urol. 2011;59:923-8.

41. Vredevoe DL, Woo MA, Doering LV, Brecht ML, Hamilton MA, Fonarow GC. Skin test anergy in advanced heart failure secondary to either ischemic or idiopathic dilated cardiomyopathy. Am J Cardiol. 1998;82:323-8.
42. Davos $\mathrm{CH}$, Doehner W, Rauchhaus M, Cicoira M, Francis DP, Coats AJ, et al. Body mass and survival in patients with chronic heart failure without cachexia: the importance of obesity. J Card Fail. 2003;9:29-35.

Correspondence address: Yong Fang, $\mathrm{MD}, \mathrm{PhD}$

Department of Urology

First Affiliated Hospital of Sun Yat - Sen University Guangzhou 510080, China Telephone: + 862087755766 R 8227 E-mail: fangyongsysu@sina.com 